Elżbieta Konończuk

\section{Black Women in Biographical Narratives}

DOI: $10.18318 /$ td.2017.en.2.6

$\mathbf{T}$ he book opens with two scenes. In the first, which takes place in a Paris salon at the start of the nineteenth century, a full-figured black woman with particularly well-defined buttocks dances wildly and passionately before the representatives of Europe's upper class. In the second scene, which takes place in the twentieth century, a black woman, beautiful and self-assured, walks down a catwalk. With these two scenes Anna Wieczorkiewicz begins her book entitled Czarna kobieta na biatym tle. Dyptyk biograficzny [Black Woman on a White Background: A Dual Biography], whose heroes are Saartjie Baartman and Waris Dirie. Both born and raised in Africa, they achieved fame in Europe, though the exact nature of that fame was determined by the culture and the times they lived in.

The researcher retells the story of black women whose life stories have been told many times before and are firmly established in the collective imagination through popular culture. Therefore, the author's goal is not to provide just another iteration of the biographies of these two women, but rather to give a self-conscious reappraisal of the methods of constructing biographical narratives and the role of the implied author within these narratives.
Elżbieta Konończuk

- Professor at the University of Bialystok. She is the author of: Literatura i pamięć na pograniczu kultur (Erwin Kruk-Ernst Wiechert-Johannes Bobrowski) [Literature and Memory at the Crossroads of Cultures] (2000), W poszukiwaniu dostępu do przeszłości. O powieściach warsztatowych Hanny Malewskiej $\mathrm{i}$ Jacka Bocheńskiego [Searching for Access to the Past] (2009). Co-editor of monographs: Przestrzenie geo(bio) graficzne w literaturze [Geo(bio)graphical Space in Literature] (2015), Geograficzne przestrzenie utekstowione [Textualizing of Geographical Space] (2017). Deputy editor of Białostockie Studia Literaturoznawcze. 
The first part of the book is devoted to methodological considerations of biography defined as a "construct created, transmitted, and functioning in accordance with cultural norms,"1 therefore having multiple variants that are a source of knowledge about those who tell them and their world. A biography - of a historical figure, for example, that has been the subject of numerous works written in different periods - becomes a particular type of anthropological narrative as subsequent authors face the task of understanding not only the figure they attempt to describe, but also the biographers preceding them, whose methods of research and expression were determined by the times and the prevailing discourses. The author of this dual biography - in light of today's dominant feminist and postcolonial discourses which lend themselves to both Saartjie Baartman and Waris Dirie - proposes a story that is focused on both the body and biography, as she is particularly interested in the mechanism which allows discourses to take individuals into their possession, and as Wieczorkiewicz writes:

shape their bodies and biographies, and then take control over them and use them for their own purposes - scientific, social, political, economic, artistic, leisurely...2

The biography of Saartjie - the Black Venus, as she was called - is built as a conjunction of two kinds of narrative. The first constructs the bodily identity of its hero and the second her onstage identity. The topic of corporeality arises from the discourses of natural history, anthropology, and medicine, all of which attempt to observe, describe, and classify phenomena. William Burchell, a naturalist and painter, at the beginning of the second decade of the nineteenth century in his travel notes and sketches lays the groundwork for European presuppositions relating to the image of the African world the natural habitat of the Khoikhoi Venus. The accounts of naturalists who travelled through Africa at that time, which became an integral part of natural history, fall somewhere between an innocent appreciation of the natural environment and a narrative of conquest that attempts to submit the world to European authority. From the accounts of expeditions to the south of Africa - provided by Peters Kolb, Anders Sparrman (one of the Apostles of Linnaeus), and William Peterson - the figure of a Hottentot emerged and Saartjie became its embodiment, serving as a specimen in the research of Hottentot

1 Anna Wieczorkiewicz, Czarna kobieta na białym tle. Dyptyk biograficzny (Kraków: Universitas, 2013), 8.

2 lbid., 10. 
attributes. Georges Cuvier, a naturalist and zoologist, played a prominent part in the construction of the image of Black Venus, and subjected her to anatomical examination and introduced her into the field of scientific inquiry as a creature with ape-like movements and lips pronounced like an orangutan. Henri de Blainville also left a detailed report describing Saartjie's body, incorporating it, as an object of a certain kind, into the evolutionary order of nature. Both zoologists view the subject of their research with utmost precision, they study each anatomical detail and determine the exact color of each body part. Their interest and excitement is aroused by wide hips, pronounced buttocks, but most of all by the so-called hottentot apron, that is the overly elongated labia minora. Another naturalist and traveler, François Le Vaillant, as an expert on the anatomy of the women from the Cape, enriches contemporary knowledge of that intimate anatomical detail by popularizing it through drawings brought back from trips to Africa. Sketches of fauna and flora made by travelers broadened the knowledge of faraway lands and supplementing such a collection with the depiction of a hottentot woman not only completed the picture of the natural order, but was also a gesture of asserting possession of that exotic world.

Saartjie's biography is a conjunction of two types of narrative: one focused mainly on its heroine's corporeality and the other relating to the ways of presenting her body. The nineteenth century, fascinated by exoticism and the curiosities lining the walls of studies, found a representative of the last subspecies, which was made up of natural monstrosities, namely the Homo monstrosus, as the Linnaean order of natured classified the Hottentots. A human on display - to recall the author's remark that monstrare means to show - became the subject of various curatorial, exhibitory, and museum practices. Anna Wieczorkiewicz considers these practices as constitutive of that systematic biography of Black Venus which she defines as her onstage identity. She appeared on the stage of the European world whose ideas of the exotic countries and their inhabitants were formed by drawings of travelers which revealed the oddities of the Black Continent. The European scene prepared numerous settings for her. The Liverpool Museum arranged a habitat scenery in which a faraway African landscape served as a backdrop for Saartjie emerging from a hut. Parisian shows, on the other hand, proposed different attractions for different audiences: on fairground stages, the Hottentot Venus appears with a collar on her neck and was led on a leash for the amusement of the crowd; in the salons she danced and played on African instruments; she also also performed for academics, broadening their knowledge of the exotic world.

Saartjie's posthumous biography was constructed by scholars within exhibition venues. Black Venus, musealized, therefore became an exhibit, 
a kind of reference specimen. Her body, illegally transferred to the National Museum of Natural History in Paris after her death, was dissected according to the anatomical principles, and the parts which were preserved, researched, and meticulously catalogued then served as a model for a plaster cast. The intimate body part, the hottentot apron, preserved in alcohol, was also preserved in an exceptionally naturalistic description made by Cuvier. That is how museum life began for Saartjie whose skeleton, together with a plaster cast of her body, was donated in 1937 as part of an anthropological collection to the newly opened Museum of Man in Paris. The museum career of Black Venus was still to have a few noteworthy turns. In the 1980s, Stephen Gould, a paleontologist and evolutionary biologist, based his impressions of a visit to the Museum of Man on the observation that alongside the preserved sexual organs of the Hottentot Venus was paradoxically displayed the preserved brain of Pierre Paul Broka - an anthropologist and discoverer of the center of articulate speech in the brain. This fact became the basis for reflecting upon the awareness of nineteenth-century scientists who laid out the foundations of racist ideology. Gould points out that he has not found either a female brain or male genitals in the collection. In 1994, the cast of Saartjie's body was lent to an exhibition of nineteenth-century ethnographic sculpture organized at the Musée d'Orsay, where it attested to the ways of depicting and experiencing Others, before being returned to storage.

A new chapter in the posthumous biography of Saartjie was opened by Nelson Mandela who in 1994, during Francois Mitterrand's visit to South Africa, requested the return of her remains. In 2002, after several years of negotiations - complicated by the fact that the body of Black Venus, as a museum holding, had the status of national heritage -they were finally transported to Cape Town with the consent of the French National Assembly. The burial ceremony was held on August 9th, the National Women's Day in South Africa, and it was an important event for the community. The President's speech summing up Saartjie's life voyage recast her biography as that of a national hero and, from that point onward, her life became a constructive element of narratives of identity, post colonialism, and resentment that unmask the western barbarity towards otherness.

An important article that led to a discussion of the interpretation of Saartjie's biography was a text by Saner L. Gilmann from 1985, titled Black Bodies, White Bodies: Toward an Iconography of Female Sexuality in Late NineteenthCentury Art, Medicine, and Literature, in which the author suggestively inscribes Saartjie into the context of artistic representations (images, erotic photography) of a black, sexualized woman. He constructs his argument on the thesis which claims that at the center of the colonial mindset lay the perception of "indigenous populations" as requiring control. Women were also viewed from 
this perspective - and especially black women, who were associated with primitive and savage sexuality, resulting from a lack of self-control. Gilman's article, due to the controversial thesis presented within it, started a discussion on the biography of the Hottentot Venus, who once more became a heroine of narratives, this time within the discursive space of the modern humanities. These narratives are focused - as the author of the reviewed volume points out - on the figure of the mute black women, on the one hand, and on the agency of her voice, on the other. A representative of the feminist approach, Anne Fausto-Sterling - by giving up illustrational material, including the caricatures exaggerating the anatomical features considered deviant and monstrous - relinquishes the rhetoric inherited from the colonial discourse and proposes a search for a new language that would enable the description of similar phenomena. She offers a reading of the history of Black Venus - whose body was turned into an object of interpretation by Europeans who, therefore, deprived her of any vital power - as an illustration of the mechanisms of producing racist ideology. The object of interest for contemporary narratives has, consequently, shifted to the agency of the heroine who has previously been depicted as mute and docile. Her identity, defined by actions, thoughts, and emotions, is actualized in artistic representations. In a poem published in 1989 by an African-American poet, Elizabeth Alexander, the Hottentot Venus speaks in her own voice about her degradation and about her dreams, advocating for the self-determination of black women. In 1996 Suzan-Lori Parks staged her controversial play at The Public Theater in New York. The play, by alluding to fairground show practices, unmasks the mechanism of the entertainment business and of presenting oneself for show. The viewer is faced with questions of the consumption of culture and his own complicity in putting the Other on show.

Anna Wieczorkiewicz - by introducing herself into her narrative as a researcher neutral to the story being told - decides to listen to the voices of those who for more than two centuries told the story of Saartjie Baartman, in order to apprehend the strategies of constructing meanings attributed to their heroine, which feature in their narratives. The researcher navigates numerous discourses and, with the precision of an archeologist, reveals subsequent layers of meaning accrued around Black Venus, which have built up in a palimpsestic fashion, turning her biography into an elaborate text of culture. The author's research strategy can be likened to the approach of a historian who, immersed in the archives, attempts to reach the truth not through interpretation, but rather through the richness of sources presented to the reader who themselves must create a narrative upon their basis. Of course, we have to be mindful of the fact that the choice of sources and their structuring also bear the mark of interpretation. 
The second of the pair of biographies is that of Waris Dirie, a Somali-born black model, who went on to make a spectacular career on the runways of Milan, London, New York, and Paris. The story of Waris becomes entangled in the contexts of Josephine Baker's history, who, by exposing her physicality through ferocious dancing, has reinforced the assumption of the eroticism of black women. A reference to Baker's biography helps to comprehend Europe's historically turbulent infatuation with Africa, on the one hand, and the mechanisms of commodification of black women's biographical narratives, on the other.

Two centuries separate the lives of Waris Dirie and Saartjie Baartman, and the Somali model - in contrast to her silent predecessor - has the opportunity to influence her public image, which she does as the author of autobiographies: Desert Flower, Desert Dawn, Desert Children, Letter to My Mother, and Schwarze Frau, weißes Land. Anna Wieczorkiewicz shows the way in which Waris proceeds with her self-presentation, utilizing narrative patterns solidly grounded in culture. The author of the Letter to My Mother proposes, for example, the mode of a fairytale narrative to present the Western world, to where a little girl journeys, as distant and dangerous, though decent people whom she encounters help her achieve happiness. The autobiographical stories of Waris bear the sign of identity narratives, focused on self-knowledge and therapy, which belong to an "exhibitionist culture" that stems from the demand for intimate confessions made in public. Confessions addressed to the mother - that are at the same time an accusation of complicity in the suffering and humiliation of the daughter - are a form of therapeutic self-narrative, where the question of the author's identity resurfaces time and again.

In her previous books - Muzeum ludzkich ciat. Anatomia spojrzenia [Musem of Human Bodies: The Anatomy of Looking], ${ }^{3}$ Apetyt turysty. O doświadczeniu świata w podróży [A Tourist's Appetite: Experiencing the World Through Travel], ${ }^{4}$ Monstruarium $^{\mathbf{5}}$ - Anna Wieczorkiewicz proposes various anthropological narratives, always exemplifying the process of enquiry into the researched phenomenon and its reception. Considering narrative to be an analytical instrument, she generally constructs it upon an epistemological metaphor that visualizes the analytical process. It is principally a metaphor of the museum, gallery, or a cabinet of curiosities, which introduce the reader into a space of astonishing

3 Anna Wieczorkiewicz, Muzeum ludzkich ciał. Anatomia spojrzenia (Gdańsk: słowo/obraz terytoria, 2000).

4 Anna Wieczorkiewicz, Apetyt turysty: o doświadczaniu świata w podróży (Kraków: Universitas, 2008).

5 Anna Wieczorkiewicz, Monstruarium (Gdańsk: słowo/obraz terytoria, 2009). 
occurrences, giving them the impression of direct experience. The author's scholarly imagination is not only associated with the experience of the museum but also with the experience of travel, and therefore the metaphor of voyage also gives structure to the narrative order of her works.

Czarna kobieta na biatym tle pursues the question researched in previous works - that of corporality as a historically and culturally mediated phenomenon. In this case the matter at hand puts particular demands on the researcher as the bodies of black women - the subject of her inquiry - are in fact displayed, made available to the public, which means that their study might easily skew towards interest in curiosity or deformation. The author in this book also asserts a self-referential stance, revealing the interpretative difficulties associated with the nature of scrutinized documents. Therefore, she leaves traces of her presence in the text, regularly underscoring her impartiality towards the presented subject and at the same time problematizing her own actions, utilizing narrative and compositional patterns for this end, which allows one to consider this book as representative of narrative anthropology.

Translation: Rafat Pawluk 